\title{
A REVIEW OF THE CAWTHRON INSTITUTE'S WORK ON PASTURE DEVELOPMENT ON PAKIHI LANDS
}

\section{E. T. Chittenden}

Pedologist, Cawthron Institute, Nelson

IN THE EARLY DAYS of European settlement on the West Coast, high hopes were held for farming on the pakihi lands, for here was land with no forest to be cleared before development to pastures. All that was required to gain pastoral land was to drain the swamps, sow seed and maybe some fertilizer. How right this proved to be; but the problems of drainage were not anticipated. With a high water-table perched on an impervious humus-iron pan and negligible lateral or surface drainage, the task proved discouraging to say the least, and after initial abortive attempts most of the land was abandoned by farmers.

However, a few farmers persisted in their endeavour to establish pastures and, with the help given by agricultural research workers, some success was attained. Prominent among the research workers taking an interest in the problem of pakihi soils were B. C. Aston, Research Chemist, and G. de S. Baylis, Fields Instructor, Department of Agriculture. As early as 1910, recommendations of lime, phosphate and potash were given at similar rates to those used today, but basic slag, rock phosphates and burnt lime were the forms of fertilizer preferred at that time (Aston, 1910). Good stands of grasses and legumes were established on trial plots where both lime and phosphate were used, whereas plots without fertilizer were barren. These men were optimistic for pasture development on large areas of the West Coast pakihi lands where there was some slope giving surface drainage, but expressed concern at the high cost of fertilizers on the West Coast.

Attempts to improve subsoil drainage by shattering the underlying pan with the use of explosives achieved some success, and, although the method may be impracticable, the area-so-treated--is considerably drier_today than the untreated land.

At this time, attention was also being paid to the pakihi lands in Golden Bay and F. G. Gibbs, a schoolmaster at $\mathrm{Nelson}$, must be regarded as a pioneer here. He bought land at Onekaka and, helped with advice received from Baylis 
and later from Cawthron Institute officers, established pastures in various ways and carried out many fertilizer trials. Comments on the better drainage of pakihi soils at Golden Bay compared with that of the West Coast soils were made by Baylis in 1912. He stated that there was generally a greater depth of topsoil and considerable areas were naturally drier than at Westport.

The Cawthron Institute became involved with research on pakihi soils soon after its establishment in 1920. At the request of the Buller County Council, Easterfield (the Institute's first director) and Rigg conducted many experiments on land at Sergeant's Hill, Westport. A paper by Easterfield, Rigg and Bruce (1929) describes methods of pasture establishment, by ploughing, discing, fallowing or burning-off and oversowing. All methods are stated to have been successful and the production of pasture was very encouraging. Fertilizers appear to have been limited to phosphate and lime, although potash was used for hay crops.

From these trials at Sergeant's Hill, recommendations were made for sowing down a pasture as follows:

(1) Select land with a natural fall.

(2) Surface drain with shallow drains where possible.

(3) Burn vegetation.

(4) Topdress with 1 ton ground limestone and 5 cwt superphosphate or basic slag per acre.

(5) Sow grass and clover seed with $1 \mathrm{cwt}$ of inoculating soil.

(6) Brush harrow.

Following the success of these experiments at Sergeant's $\mathrm{Hill}$, the Unemployment Board agreed to facilitate the reclamation of 200 acres on the Buller Domain adjacent to the experimental plots. The project was under the control of the Lands Department but the Cawthron Institute assisted in an advisory capacity.

The sowing down, using the methods outlined above, was completed by 1936 and the pasture gave promise of success. Owing to the unemployment problem on the West Coast, it was considered an opportune time to continue reclamation of-pakihi-land, although no real test of the economic value of the 200 acres of sown pasture had been made. Accordingly, reclamation was extended by staqes until the total area developed was about 1,100 acres.

In 1938, arrangements were made to conduct a test of the economic value of dairying on 100 acres of land on the 
Buller Domain which had been sown down two years previously. This land is typical of the soil mapped as Sergeant sandy loam (Harris and Harris, 19.39). The topography is gently sloping but with areas of flat basins which remain very wet in winter. Some 35 young rnws were used for the dairy unit and records were kept of milk, butterfat production and operating costs.

In the first full season the cows did relatively well and came through the winter in good condition However, it was clear that the stocking rate was too heavv for the winter period and the number of cows was reduced to 30 for the second season. There followed a wet winter and the pastures were badly poached and spring growth was delayed. Despite hand feeding with ensilage and hay, the cows on these poached pastures did not do as well as in the previous season. After careful consideration, it was decided that the returns from the dairy unit would not be eronomic and in 1942 the project was abandoned. Conclusions arising from this dairy unit trial were:

(1) Great difficulties were encountered in carrying an economic number of stock during the winter period owing to poaching causing deterioration of pastures and loss of nutrients.

(2) The absence of dry areas of land aggravated the diffculties of handling stock during winter.

(3) The difficulty of harvesting hay and ensilage in summer owing to wet weather.

(4) Lack of shelter for stock.

The reclamation scheme covered two soils - Sergeant sandy loam, which occupied the major part of the area, and Utopia sand. Sergeant soils comprised gently sloping land but with extensive, wet basins which proved verv difficult to manage. Utopia sand was much easier to handle and much of the treated area on this soil is still maintained as good grazing land. Although subsoil drainage was ponr with Utopia soils owing to pan formation, there was a sufficient depth of soil to obtain good surface drainage.

Similar fertilizer responses on pastures were found as on Sergeant soils. The land did not poach and the harvesting of hay and ensilage for winter feeding was less difficult.

Some conclusions arising out of the reclamation scheme were:

(1) One ton ground limestone and $5 \mathrm{cwt}$ superphosphate/ acre to establish a pasture was satisfactory, with main- 
tenance applications of 2 cwt superphosphate/acre annually. Hay crops required additions of potash at $1 \mathrm{cwt} /$ acre to obtain good yields.

(2) Young cattle suffered from cobalt deficiency and copper deficiency was suspected also. A cobaltcopper-salt lick was used for cattle on the reclamation with good results, although it was known later that topdressings of these elements would have been more satisfactory.

(3) Borax topdressings were required for turnips and swedes to correct boron deficiency symptoms causing brown-heart.

(4) The provision of shelter was desirable. Radiata pine and eucalypts grew satisfactorily on dry areas provided phosphate was supplied to the soil.

(5) Where stock could be transferred to dry land in winter, established pastures on Sergeant soils could be maintained satisfactorily but not otherwise. If retained in winter, stock should be greatly reduced in numbers and confined to young animals.

(6) Under the existing methods of treatment and handling of stock, the returns from a farm established on Sergeant soils were not economic.

(7) It is interesting to note that a considerable area of the 200 acres on the Buller Domain, despite receiving little treatment since 1942, has not reverted to natural pakihi vegetation. Clumps of manuka are conspicuous but there is a high proportion of poor grasses remaining. Clovers are dormant but there is little doubt that a good dressing of lime and phosphate would rejuvenate the pasture and greatly increase production on the area.

During these investigations on pakihi soils at Westport, the Institute was also interested in the development of pastures on pakihi soils at Golden Bay where, as was mentioned earlier, F. G. Gibbs was developing land: With H. Ives and later F. J. Page as managers, he successfully ran a dairy herd for many years, and, although problems of manage ment-and fertilizer treatment were encountered, the venture was considered a success. Mr Gibbs sold his property to $\mathrm{Mr}$ Ives and $\mathrm{Mr}$ Page purchased an adjacent block. On these two blocks, more particularly the latter in recent years, the Institute continued its investigations.

There are two soils mapped on pakihi land in Golden Bay, namely, Kotinga and Onahau. Together they occupy 
about 15,000 acres. It is on Onahau soils that Cawthron investigations have been made. Kotinga soils are shallow and often stony to the surface. Pastures may be established by the same practices used on Onahau soils but the stony surface in many areas impedes cultivation.

Onahau soils are gley podzols. Topography is flat to gently undulating, and the land surface is dissected by steep-sided gullies at frequent intervals. Surface drainage is good throughout most of the area. Rainfall in Golden Bay ranges from 60 to $100 \mathrm{in}$. per annum. Soil profiles vary with topography but on gently undulating land a common profile is as follows:

$$
\begin{aligned}
& 1 \text { to } 2 \text { in....... raw humus. } \\
& 4 \text { in .................. dak grey loamy fine sand ; w eak coarse } \\
& \text { blocky structure. } \\
& 11 / 2 \text { in ............. whitish grey fine sand; structureless. } \\
& 7 \text { in ..................vey pale grey fine sand; very weak } \\
& \text { coarse blocky structure. } \\
& 2 \frac{1}{2} \text { in ............. dark brown sandy loam ; humus stained, } \\
& \text { with small concretions; moderately } \\
& 6 \text { in.................. yellowish brown gravelly sandy loam; }
\end{aligned}
$$

This, as can be seen, is only a juvenile stage of a West Coast gley podzol. Nevertheless, the drainage is impeded by a water-impervious pan and under natural conditions grows rushes, umbrella fern and stunted manuka, with most areas unproductive for agriculture.

Chemical analyses of a soil profile taken from an undisturbed site with no fertilizer treatment are given in Table 1.

Onahau soils have two important advantages compared with the pakihi soils of the West Coast, (1) better surface drainage, and (2) a drier climate, and, although wet conditions in the winter months may cause management difficulties, droughty conditions in the summer are of more concern.

Investigations with fertilizer responses on pastures showed some curious results. After sowing down with an initial application of 1 ton of lime/ acre, further applications, even several years later, depressed growth. (It is of interest to note in the early trials at Westport that no better response was obtained from 2 tons of lime than from 1 
Development on Pakihi Soils

TABLE 1: CHEMICAL ANALYSES-ONAHAU FINE SAND

\begin{tabular}{|c|c|c|c|c|c|c|c|c|c|}
\hline \multirow[b]{2}{*}{ Depth } & \multirow{2}{*}{\multicolumn{2}{|c|}{ 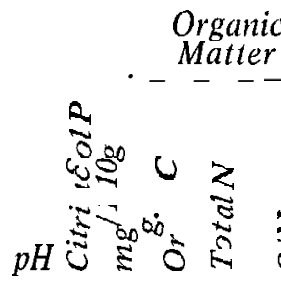 }} & & \multicolumn{4}{|c|}{ Cation-exchange } & \multicolumn{2}{|c|}{ Properties } \\
\hline & & & $\frac{3}{0}$ & 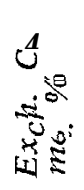 & 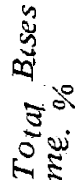 & 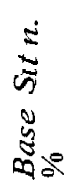 & 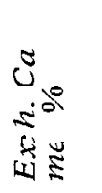 & 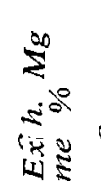 & 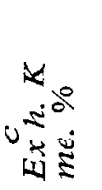 \\
\hline $\begin{array}{c}0-1 \\
1-5 \\
5-6 \\
6-13 \\
13-16 \\
16-22\end{array}$ & $\begin{array}{l}4.4 \\
4.5 \\
4.6 \\
5.0 \\
5.0 \\
5.6\end{array}$ & $\begin{array}{lll}1 & 4.5 & 0.18 \\
1 & 2.1 & 0.11 \\
1 & 0.7 & 0.05 \\
1 & 0.6 & 0.04 \\
3 & 2.1 & 0.10 \\
2 & 1.3 & 0.04\end{array}$ & $\begin{array}{l}25 \\
19 \\
15 \\
16 \\
21 \\
31\end{array}$ & $\begin{array}{r}10.6 \\
5.3 \\
2.4 \\
1.6 \\
12.1 \\
9.2\end{array}$ & $\begin{array}{l}1.6 \\
0.5 \\
0.1 \\
0.05 \\
0.1 \\
0.1\end{array}$ & $\begin{array}{c}15 \\
9 \\
4 \\
3 \\
0.8 \\
0.5\end{array}$ & $\begin{array}{l}0.6 \\
0.07 \\
0.05 \\
0.01 \\
0.05 \\
0.05\end{array}$ & $\begin{array}{l}0.5 \\
R .2 \\
0.06 \\
0.01 \\
\mathbf{0 . 1 5} \\
\mathbf{0 . 0 6}\end{array}$ & $\begin{array}{l}\mathbf{0 . 1 7} \\
0.02 \\
0.02 \\
0.01 \\
\mathbf{0 . 0 0 2} \\
\mathbf{0 . 0 1}\end{array}$ \\
\hline
\end{tabular}

ton.) Molybdenum also gave a depression in growth when applied at 4 ounces of sodium molybdate/acre. Yet 2 ounces gave Increased growth although this increase was not evident until the year following application. Whether these effects of lime and molybdenum are related is not known.

Depression in growth from liming suggested an induced trace element deficiency but trials failed to confirm this. Trials with trace elements showed slight growth responses from copper, manganese, zinc, and boron when applied separately, yet combinations of these elements gave no further response. How significant these results are is difficult to assess as there was another factor limiting growth which was discovered later. However, copper and cobalt are used periodically, as the soil contents of these elements are at critical level for stock health.

Magnesium is very low and small growth responses have been obtained from its application. This element is being investigated further. In spite of low levels of magnesium in these pastures over many years, no instances of grass staggers have been reported.

Prior to 1950, although rates of liming and various forms and rates of application of phosphatic fertilizers were investigated, no mention was made of potassic fertilizers being used. The accepted practice was to sow down a pasture with 1 ton of lime and $5 \mathrm{cwt}^{-}$of superphosphate/ acre. Maintenance topdressings were 2 to 3 cwt of superphosphate/ acre annually. However, it was then found that potash gave a great increase in growth of pasture and 1 cwt of muriate of potash was included in the annual topdressing program-me. Potash applications changed the 